\title{
Definitely Better
}

National Cancer Institute

\section{Source}

National Cancer Institute. Definitely Better. NCI Thesaurus. Code C53559.

Showing obvious signs of improvement. 